\title{
BIRC5 wt Allele
}

National Cancer Institute

\section{Source}

National Cancer Institute. BIRC5 wt Allele. NCI Thesaurus. Code C49359.

Human BIRC5 wild-type allele is located in the vicinity of $17 q 25$ and is approximately $10 \mathrm{~kb}$ in length. This allele, which encodes baculoviral IAP repeat-containing protein 5, is involved in the prevention of apoptotic cell death. 